\title{
Kualitas Pelayanan E-KTP Di Kecamatan Ciputat Timur Kota Tangerang Selatan
}

\author{
Pradietya Dimas Chairrizal ${ }^{(1)}$, Retnowati WD Tuti ${ }^{(2)}$ \\ (1)(2) Program Studi Magister Ilmu Administrasi FISIP UMJ, Tangerang Selatan-Banten, Indonesia \\ ${ }^{(1)}$ Email Korespondensi: pradietyadimas93@gmail.com ${ }^{(2)}$ retnowatiwdtuti@yahoo.com
}

\begin{abstract}
Abstrak: Peluncuran program kartu kependudukan elektronik (e-KTP) telah menjadi perhatian pemerintah berbagai daerah di Indonesia, tidak terkecuali Pemerintah Kota Tangerang Selatan. Namun setelah tahun 2011 ditemukan banyak masyarakat belum melakukan perekaman e-KTP di Kecamatan Ciputat Timur, kondisi tersebut menimbulkan pertanyaan akan banyaknya warga yang belum mengganti kartu kependudukannya. Maka perlu kiranya mengetahui kualitas pelayanan e-KTP, yang juga menjadi tujuan penelitian. Pendekatan dalam penelitian ini menggunakan pendekatan deskriptif kualitatif, dan pengumpulan data menggunakan teknik wawancara, observasi, dan dokumentasi. Dari data temuan lapangan dan analisis dimensi kualitas pelayanan, maka dapat dikatakan pelayanan e-KTP di Kecamatan Ciputat Timur masuk dalam kualitas baik. Dimensi Responsiveness (daya tanggap), Assurance (jaminan), dan Empathy (perhatian) pelayanan e-KTP terlaksana dan mendapatkan respon yang baik. Dimensi Responsiveness terlihat dari pegawai yang informatif dan komunikatif pada proses pelayanan e-KTP, Dimensi Assurance tergambar dari tanggung jawab pegawai hingga memastikan kenyamanan dan keamanan data penerima e-KTP, dan Dimensi Empathy tampak dari perhatian dan kesopanan kepada penduduk serta penggunaan bahasa yang baik dalam pelayanan e-KTP. Pada Dimensi Tangibility terdapat sarana dan prasarana yang baik, namun masih minim sarana informasi serta fasilitas lahan parkir yang tidak memadai. Selanjutnya Bidang Reliability terdapat penundaan dalam penerimaan e-KTP, sehingga penduduk harus menunggu beberapa hari untuk mendapatkan e-KTP.
\end{abstract}

Kata kunci: $e-K T P$; Dimensi Pelayanan; Kualitas Layanan.

\begin{abstract}
The launch of the electronic residence card (e-KTP) program has caught the attention of various regional governments in Indonesia, including the South Tangerang City Government. However, after 2011 it was found that many people had not recorded their e-KTP in East Ciputat District, this condition raised questions about the number of residents who had not changed their residence cards. So it is necessary to know the quality of e-KTP services, which is also the purpose of the research. The approach in this study used a qualitative descriptive approach, and data collection used interview, observation, and documentation techniques. From the data on field findings and analysis of the dimensions of service quality, it can be said that the e-KTP service in East Ciputat District is in good quality. Dimensions of Responsiveness (responsiveness), Assurance (guarantee), and Empathy (attention) e-KTP services are implemented and get a good response. The Responsiveness dimension can be seen from employees who are informative and communicative in the e-KTP service process, the Assurance dimension is reflected in the responsibility of employees to ensure the comfort and security of data on e-KTP recipients, and the Empathy dimension is seen from the attention and politeness to the population and the use of good language in e-KTP service. In the Tangibility dimension, there are good facilities and infrastructure, but there is still a lack of information facilities and inadequate parking facilities. Furthermore, in the Reliability sector, there was a delay in receiving $e-K T P$, so that residents had to wait several days to get an $e-K T P$.
\end{abstract}

Keywords: e-KTP; Service Dimensions; Service Quality.

Article History:

Received 23 April 2021; Revised 31 Mei 2021; Accepted 25 Juni 2021

\section{PENDAHULUAN}

Negara Indonesia yang merupakan negara hukum dalam pelaksanaan tata kelola pemerintahan senantiasa berdasar pada hukum, tidak terkecuali terkait pencatatan penduduk atau masyarakat dalam negara Indonesia. Pencatatan kependudukan tersebut telah diamanatkan 
dalam Undang-Undang Nomor 23 Tahun 2006 Tentang Administrasi Kependudukan Pasal 2 bahwa setiap warga Negara mempunyai hak untuk memperoleh dokumen kependudukan, pelayanan yang sama, perlindungan data pribadi dan kepastian hukum atas dokumen kependudukan. Sehingga pemerintah wajib menjalankan amanah undang-undang tersebut sebagai bentuk pemberian hak warga negara untuk mendapatkan dokumen kependudukan.

Pencatatan penduduk yang telah menjadi tanggung jawab Negara atau pemerintah dalam pelaksanaannya berujung pada Pemerintah Daerah, oleh karena itu Pemerintah telah memunculkan sebuah kebijakan yaitu Sistem Informasi Administrasi Kependudukan (SIAK) yang berdasar pada Undang-Undang Republik Indonesia Nomer 24 Tahun 2013 Tentang Administrasi Kependudukan. Dengan adanya SIAK tersebut telah menunjukkan pelayanan pencatatan kependudukan atau sipil diperkuat teknologi informatika yang dapat dijalankan oleh pemerintah pusat maupun daerah.

Menindak lanjuti kebijakan pemerintah dalam pencatatan kependudukan, pada tahun 2011 pemerintah meluncurkan program kartu kependudukan elektronik (e-KTP) yang menjadi perhatian pemerintah pusat dan juga berbagai daerah di Indonesia. Kondisi tersebut menunjukkan penggunaan teknologi informasi dan komunikasi dalam merekam serta mencatat penduduk sipil sebagai warga negara Indonesia. Namun begitu, kemajuan pencatatan kependudukan atau sipil tersebut mengalami berbagai tantangan dalam pelaksanaan pemberian layanan publik, khususnya pelayanan e-KTP, pada pemerintah maupun pemerintah di berbagai daerah di Indonesia.

Dalam menilai kulaitas pelayanan e-KTP, Bates dan Hoffman (1999) dalam Sukoco dan Nilowardono (2009) menyebutkan bahwa kualitas layanan merupakan penilaian pelanggan terhadap proses penyediaan jasa. Selain itu, Tjiptono (2005) menjelaskan kualitas pelayanan sebagai suatu tingkat keunggulan yang diharapkan dimana pengendalian atas tingkat keunggulan tersebut bertujuan untuk memenuhi kebutuhan pelanggan.

Dari penjelasan tersebut dapat dijelaskan bahwa pelayanan e-KTP sebagai salah satu bentuk pelayanan publik dalam pencatatan kependudukan memiliki tujuan untuk memenuhi kebutuhan pelanggan, dalam hal ini masyarakat Indonesia sebagai pelanggan yang berhak mendapatkan pelayanan e-KTP. Hal tersebut merupakan amanah Undang-undang yang telah menjadi tanggung jawab pemerintah pusat beserta pemerintah daerah di Indonesia, dalam pelaksanaanya telah memunculkan tantangan dan permasalahan tersendiri di berbagai pemerintah daerah.

Kecamatan Ciputat Timur yang masuk dalam wilayah Pemerintah Kota Tangerang Selatan dalam melaksanakan perekaman dan pencatatan e-KTP juga telah mengalami hambatan dan tantangan dalam pelaksanaannya. Hal tersebut terlihat dari pengamatan penulis, dimana masih terdapat masyarakat yang dihadapkan dengan proses birokrasi yang berbelit yang menyebabkan pengadaan e-KTP tersebut lambat diperoleh masyarakat. Data pada masyarakat Kecamatan Ciputat Timur menunjukkan rincian jumlah Laki-Laki 89.603 dan Perempuan 94.962, dari data tersebut yang belum melakukan perekaman e-KTP sebanyak 10.029 orang.

Dari data tersebut di atas telah menunjukkan banyaknya masyarakat yang belum melakukan perekaman e-KTP, kondisi tersebut disebabkan oleh pelayanan yang belum berjalan dengan maksimal sehingga menyebabkan tingginya jumlah masyarakat yang belum melakukan perekaman e-KTP. Kondisi tersebut memberikan dampak dan menghambat keperluan administrasi masyarakat dalam menjalankan aktifitasnya yang membutuhkan eKTP. Oleh karena itu perlu kiranya menggali kualitas pelayanan e-KTP di Kecamatan Ciputat Timur. Sehingga dari hasil penelitian ini diharapkan dapat menggali kualitas pelayanan serta menjadi masukan bagi pemerintah Kota Tangerang Selatan dalam meningkatkan kualitas pelayanan e-KTP khususnya di Kecamatan Ciputat Timur. 


\section{METODE PENELITIAN}

Penelitian ini dilakukan sebagai upaya untuk mengetahui lebih mendalam tentang kualitas pelayanan e-KTP di Kecamatan Ciputat Timur Kota Tangerang Selatan. Penelitian ini menggunakan metode kualitatif yang akan mendeskripsikan dan menguraikan kualitas pelayanan e-KTP pada masyarakat di Kecamatan Ciputat Timur, Kota Tangerang Selatan. Pendekatan penelitian kualitatif menurut Meleong (2004, 131) mengartikan data yang dikumpulkan bukan berupa angka-angka, melainkan data tersebut berasal dari naskah wawancara, catatan lapangan, dokumen pribadi, dan dokumen resmi lainnya. Selanjutnya menurut Usman dan Akbar (2004; 81) Metode kualitatif berusaha memahami dan menafsirkan makna suatu peristiwa interaksi tingkah laku manusia dalam situasi tertentu menurut perspektif peneliti sendiri. Teknik pengumpulan data yang digunakan dalam penelitian ini mengacu pada penjelasan Patton $(2002 ; 4)$ yang menunjukkan tiga jenis pengumpulan data kualitatif yaitu: wawancara mendalam dan terbuka, Observasi, dan dokumen tertulis. Pengumpulan data dalam penelitian kualitatif sama pentingnya dengan penentuan sampel penelitian, metode dalam pengumpulan data sangat bervariasi sesuai dengan jenis informasi yang dicari, pertanyaan penelitian dan sumberdaya yang dimiliki, dan tidak ada metode benar atau salah dalam situasi tertentu atau metodologi tertentu (Alston dan Bowles, 2003; 66).

Pemilihan informan dalam penelitian ini mengacu pada penjelasan Sugiono $(2013 ; 96)$ bahwa informan adalah seseorang yang telah diketahui mempunyai pengetahuan, pengalaman, dan memahami permasalahan dalam penelitian. Oleh karena itu dalam penelitian ini pemilihan informan ditentukan menggunakan teknik purposive sampling, dimana bermakna penentuan sampel atau informan dilakukan dengan pertimbangan tertentu. Informan dalam penelitian ini telah ditentukan yang meliputi Birokrat (Kepala Kecamatan Ciputat Timur), Aparatur pemerintah (Kepala dan staff seksi pemerintahan), dan masyarakat (penerima layanan e-KTP), mengingat berbagai pihak tersebut dipilih sesuai dengan kompetensi dan sumber informasi yang ingin digali dalam penelitian ini.

\section{HASIL DAN PEMBAHASAN}

Pemaparan mengenai hasil temuan lapangan dalam penelitian ini akan dibagi dengan mengacu pada dimensi kualitas pelayanan dalam melihat kualitas pelayanan e-KTP di Kecamatan Ciputat Timur, Kota Tangerang Selatan. Secara garis besar dalam implementasi dari kebijakan pemerintah mengenai pelaksanaan program e-KTP di Kecamatan Ciputat Timur mengacu pada Undang-Undang yang telah ditetapkan oleh pemerintah dan Perda Nomor 9 Tahun 2011 Tentang Administrasi Kependudukan Kota Tangerang Selatan Tahun 2016. Segala bentuk tahapan pelaksanaan Pelayanan e-KTP di Kecamatan Ciputat Timur khususnya perekaman e-KTP sudah ada ketentuannya. Seperti sosialisai, waktu pelaksanaan, proses pendaftaran hingga tahapan pelayanan e-KTP. Sehingga berbagai aspek tersebut dapat dijadikan acuan untuk melihat kulaitas pelayanan e-KTP yang dijalankan oleh pemerintah Kecamatan Ciputat Timur bagi masyakat penerima layanan.

Dalam menganalisis dan membahas kualitas pelayanan e-KTP di Kecamatan Ciputat Timur dalam penelitian ini mengacu pada lima dimensi kualitas suatu pelayanan yang telah dijelaskan oleh Kotler dan Keller (2009), Payne dalam Djati dan Darmawan (2005), Tjiptono dan Chandra (2005). Lima dimensi kualitas pelayanan tersebut diantaranya yaitu; Tangibility (bukti langsung), Reliability (keandalan), Responsiveness (daya tanggap), Assurance (jaminan dan kepastian), dan Empathy (perhatian). Masing-masing dari lima prinsip kualitas layanan tersebut akan dilakukan analisis dan pembahasan lebih lanjut di bawah ini.

\section{Tangibility (Bukti Langsung)}

Seperti yang disebutkan Tjiptono dan Chandra (2005; 133), bukti langsung (Tangibles) meliputi fasilitas fisik, perlengkapan, pegawai, dan sarana komunikasi. Penjelasan tersebut 
memberikan pemahaman bahwa kualitas pelayanan e-KTP di Kecamatan Ciputat Timur dapat dilihat dari bukti langsung (Tangibles) seperti fasilitas fisik, perlengkapan pegawai, dan sarana komunikasi dalam memberikan pelayanan e-KTP di Kecamatan Ciputat Timur. Dipahami bahwa dalam Pelayanan e-KTP diperlukam kemampuan meliputi fasilitas fisik, perlengkapan yang memadai, pegawai yang mendukung dan mumpuni, serta komunikasi juga koordinasi yang baik untuk melayani masyarakat memegang peranan yang sangat penting dalam kesuksesan suatu pelayanan. Terkait untuk suksesnya pelayanan e-KTP yang dicanangkan pemerintah pusat, maka pemerintah Kecamatan Ciputat Timur berusaha menginformasikan kebijakan tersebut kepada masyarakat.

Kondisi pelayanan e-KTP di Kecamatan Ciputat Timur dapat dikatakan sudah baik, selain itu bentuk pelayanan e-KTP juga dapat dilakukan secara online serta memberikan ruangan atau tempat khusus yang diperuntukkan dalam proses perekaman e-KTP. Selain itu pelayanan e-KTP secara teknis sudah didukung dengan kemampuan para pegawai sebagai operator yang melakukan tanggung jawabnya dalam memberikan berbagai informasi terkait teknis pelayanan e-KTP di Ciputat Timur. Bukti langsung (Tangibility) juga dijelaskan oleh Payne dalam Djati dan Darmawan (2005) yaitu merupakan kemampuan perusahaan dalam menunjukan eksistensi dirinya, misalnya dalam hal ini gedung, fasilitas teknologi, penampilan karyawannya, dan sebagainya lebih menekankan pada bukti secara fisik atau dapat diraba keberadaannya. Penjelasan tersebut menunjukkan Tangibility sebagai bukti secara fisik atau dapat diketahui keberadaannya. Kondisi pelayanan e-KTP di Kecamatan Ciputat Timur yang telah menjadi bukti langsung (Tangibility) secara fisik atau dapat diketahui keberadaannya juga telah diungkapkan oleh para informan di bawah ini;

Informan 2 (25 Januari 2021) menyatakan bahwa:

"fasilitas untuk menunjang pelayanan e ktp kami rasa cukup baik, kami menyediakan ruang tunggu ber ac dan tempat duduk yang memadai ketika warga menunggu untuk melakukan perekaman e-KTP”. Selanjutnya informan 4 (25 Januari 2021) juga menjelaskan bahwa: "Fasilitas di Kantor Kecamatan Ciputat Timur baik, seperti ruang yang nyaman, mulai dari ruang tunggu yang ber AC, kursi yang nyaman, toilet yang bersih, ruang bermain untuk anak, tersedia nya WiFi, ketersediaan ATK untuk mengisi data. Ada salah satu fasilitas yang tidak memadai yaitu lahan parkir yang sempit."

Fasilitas fisik seperti ruangan khusus perekaman e-KTP, ruang utama pelayanan, tempat duduk bagi warga yang datang serta pegawai yang melayani juga operator perekaman e-KTP yang berjaga di ruangan perekaman dan ditempat pelayanan dirasa cukup ideal. Fasilitas yang tersedia tersebut telah membantu baik operator, staff pelayanan juga warga yang menerima pelayanan dalam memberi maupun pelayanan itu sendiri. Seperti disediakannya ruangan khusus perekaman e-KTP, tempat pelayanan, free wifi, bangku yang tersedia, serta ruangan yang ber AC sehingga memberi kenyamanan bagi warga dalam menunggu antrian.

\section{Reliability (Keandalan)}

Keandalan (Reliability) sesuai dengan penjelasan Tjiptono dan Chandra (2005; 133-135) yaitu kemampuan memberikan pelayanan yang dijanjikan dengan segera, akurat, dan memuaskan. Sehingga dapat dipahami bahwa Keandalan (Reliability) dalam pelayanan e-KTP di Kecamatan Ciputat Timur merupakan kemampuan dalam memberikan pelayanan sesuai dengan apa yang telah dijanjikan serta dapat dilaksanakan segera mungkin, akurat, dan memuaskan bagi para penerima layanan e-KTP di Kecamatan Ciputat Timur.

Penanggung jawab ataupun operator dalam pelayanan e-KTP di Kecamatan Ciputat Timur telah menunjukkan kemampuan operator atau petugas pelayanan e-KTP sesuai dengan tugas dan fungsinya. Seperti ungkapan Informan 7 (25 Januari 2021) bahwa: "pegawai 
memberikan pelayanan baik dan sudah melaksanakan tugasnya dengan tanggung jawab yang di amanahkan". Sehingga dapat dipahami bahwa pelayanan e-KTP yang telah diberikan secara maksimal, akurat, dan memuaskan sangat dirasakan oleh masyarakat sebagai penerima layanan e-KTP.

Reliability (keandalan) petugas, operator ataupun pemerintah Kecamatan Ciputat Timur dalam pelayanan e-KTP juga dapat terlihat dari pengguna jasa pelayanan e-KTP yang telah mengalami peningkatan setiap bulan atau tahunnya. Dimana diketahui bahwa pada September 2020 terdapat 142 orang yang mendapatkan pelayanan, Oktober 2020 ada 163 orang, November 2020 terdapat 190 orang, dan pada Desember 2020 mengalami peningkatan pengguna jasa layanan hingga 256 orang. Peningkatan jumlah pengguna tersebut menunjukkan keandalan petugas dalam memberikan layanan e-KTP.

Namun begitu, Reliability (keandalan) petugas, operator dalam proses pemberian layanan e-KTP juga kekurangan dalam ketepatan waktu. Hal tersebut seperti yang diungkapkan oleh Informan 7 (25 Januari 2021) berikut ini: "Pelayanan yang di berikan sudah tetapi ada sedikit kekurangan yaitu KTP tidak langsung jadi di hari itu dan harus harus menunggu dalam beberapa hari". Kondisi tersebut telah menjadikan setiap warga yang melakukan perekaman e-KTP tidak langsung mendapatkan fisik e-KTP, apabila ada permasalahan data harus diurus ke Dinas Kependudukan dan Catatan Sipil, sehingga tidak bisa diselesaikan di Kecamatan Ciputat Timur.

Keterlambatan penerimaan hasil rekam e-KTP tersebut telah menjadi ambatan tersendiri dalam proses pelayanan e-KTP di Kecamatan Ciputat Timur. Kondisi penundaan penerimaan e-KTP kepada penduduk tersebut lebih disebabkan oleh proses pencetakan e-KTP yang harus melewati berbagai prosedur yang berlaku di Disdukcapil wilayah Kota Tangerang Selatan, sehingga e-KTP tidak langsung jadi di Kecamatan Ciputat Timur atau harus menunggu beberapa waktu hingga dapat diterima oleh penduduk di Kecamatan Ciputat Timur.

\section{Responsiveness (Daya Tanggap)}

Daya tanggap (Responsiveness) sesuai dengan temuan lapangan seperti yang disebutkan di atas terlihat dari kesiap-siagaan para operator atau petugas dalam memberikan pelayanan eKTP bagi masyarakat di Kecamatan Ciputat Timur. Hal tersebut ditunjukkan oleh operator dalam membantu masyarakat yang kesulitan dalam mengurus pembuatan e-KTP, menanggapi keluhan warga, serta menunjukkan sikap ramah, sopan dan santun dalam memberikan pelayanan e-KTP bagi masyarakat di Kecamatan Ciputat Timur.

Dimensi daya tanggap (Responsiveness) dalam pelayanan e-KTP dapat dilihat dari ungkapan beberapa informan yang menjadi temuan lapangan, berikut penjelasan informan 4 (25 Januari 2021) yang menyatakan bahwa: "kalo cepat dan tanggap sih mereka cukup baik ya, pas datang kita langsung ditanyain ada kebutuhan apa. Dan mereka memberikan pelayanan dengan sopan dan ramah". Selanjutnya Informan 5 (25 Januari 2021) juga telah menjelaskan bahwa: "ya sikap yang diberikan cukup baik dan menerima keluhan masyarakat ketika saya menyampaikan keluhan e-KTP kenapa gak langsung jadi mereka menjelaskan”. Pernyataan temuan lapangan tersebut telah menunjukkan daya tanggap (Responsiveness) dalam proses pelayanan e-KTP di Kecamatan Ciputat Timur mendapatkan respon positif dari penduduk penerima layanan e-KTP..

Daya Tanggap (Responsiveness) sesuai dengan penjelasan Tjiptono dan Chandra (2005; 134) yaitu keinginan para staf untuk membantu para pelanggan dan memberikan pelayanan dengan tanggap. Penjelasan tersebut dalam penelitian ini dapat dipahami sebagai keinginan dari para petugas ataupun operator dalam membantu serta memberikan pelayanan e-KTP yang tanggap bagi masyarakat di Kecamatan Ciputat Timur.

Daya Tanggap (Responsiveness) pegawai operator pelayanan e-KTP yang cepat dan tepat secara tidak langsung telah menunjukan kesungguhan pegawai dalam memberikan pelayanan 
kepada warga, yang dimana warga akan merasa dilayani juga dimudahkan ketika mereka mengurus keperluannya di Kecamatan Ciputat Timur. Daya tanggap (Responsiveness) ini diharapkan menjadi komitmen bagi pegawai untuk menunjukan pengabdiannya sebagai abdi Negara di Kecamatan Ciputat Timur, karena sikap mereka menunjukan bagaimana semangat Kecamatan Ciputat Timur itu sendiri dalam memberikan pelayanan ksepada masyarakatnya.

Pegawai ataupun operator yang telah memberikan pelayanan secara cepat dan tepat serta menunjukkan semangat dalam memberikan pelayanan e-KTP bagi masyarakat Kecamatan Ciputat Timur telah terlihat dari pernyataan beberapa informan Informan 2 (25 Januari 2021) menyatakan bahwa: "iyaa, pegawai harus informative apabila ada mekanisme pelayanan yang berubah. Seperti dulu untuk melakukan perekaman e-KTP bisa langsung datang, namun sekarang harus daftar online. Hal itu karena kebijakan dri disdukcapil sendiri, kami kecmatan hanya mengikuti dan menginformasikan ke masyarakat".

Dalam pelayanan e-KTP petugas mampu dan memiliki daya tanggap yang baik sehingga warga merasa dilayani dalam mengurus perekaman e-KTP di Kecamatan Ciputat Timur. Sehingga dapat ditarik kesimpulan bahwa kualitas Pelayanan e-KTP di Kecamatan Ciputat Timur Sudah Baik.

\section{Assurance (Jaminan dan Kepastian)}

Jaminan (Assurance) telah menjadi salah satu prinsip dan indikator untuk melihat sejauh mana Pelayanan e-KTP di Kecamatan Ciputat Timur dan ukuran yang menunjukkan tingkat sejauh mana pelayanan yang diberikan menjadikan warga merasa aman dan yakin. Disini dapat dilihat bahwa petugas dalam melaksanakan pelayanannya, harus memberikan pelayanan yang dapat menumbuhkan rasa aman dan yakin bagi para warga dengan memiliki pengetahuan, kemampuan, kesopanan dan sifat yang dapat dipercaya. Yaitu juga dengan menunjukan dari segi komitmen dalam menjaga kerahasiaan data warga.

Jaminan (Assurance) dalam penjelasan Payne dalam Djati dan Darmawan (2005) berkaitan dengan pengetahuan dan kemampuan karyawan dalam menumbuhkan rasa kepercayaan dari pelanggannya pada perusahaan. Didalamnya terdapat unsur etika karyawan, kredibilitas karyawan, rasa aman dari pelanggan, dan unsur etika yang dimiliki oleh karyawan.

Dari hasil temuan lapangan dapat diketahui bahwa jaminan (assurance) layanan e-KTP di Kecamatan Ciputat Timur telah menunjukkan kemampuan dan pengetahuan para petugas atau operator terkait dengan IT (informasi teknologi) yang mumpuni dan menunjang dalam memberikan pelayanan e-KTP di Kecamatan Ciputat Timur. Pengetahuan dan kemampuan dalam memberikan pelayanan e-KTP tersebut juga mendapat dukungan dari Dukcapil dalam memberikan pelatihan IT (informasi teknologi) serta prosedur pelayanan e-KTP bagi para pegawai atau operator di Kecamatan Ciputat Timur.

Tumbuhnya rasa kepercayaan dari para penerima layanan e-KTP di Kecamatan Ciputat Timur terhadap kemampuan dan pengetahuan pegawai atau operator layanan e-KTP tersebut telah terlihat dari ungkapan para informan dalam penelitian. Dimana hal tersebut telah dikuatkan oleh penjelasan para informan sebagai berikut; Informan 1 (25 Januari 2021) menyatakan bahwa: "Dalam pendaftaran perekaman e-KTP kami arahakan pada website disdukcapil”. Lebih lanjut informan 2 (25 Januari 2021) menjelaskan bahwa: "Tentu harus komunikative ya, kuncinya itu. Ketika pegawai bisa memberikan penjelasan dengan baik maka warga bisa mengerti bagaimana mekanisme pelayanan yang diberikan”. Beberapa pernyataan tersebut menunjukkan kesiapan pegawai atau operator dalam memberikan pelayanan e-KTP berdasar pada tehnologi informasi dan komunikasi, serta diperkuat dengan komukasi yang baik kepada penerima layanan. Hal tersebut telah memperkuat kemampuan dan pengetahuan pegawai dalam pelayanan e-KTP, sehingga menumbuhkan rasa kepercayaan pada penduduk di Kecamatan Ciputat Timur sebagai penerima layanan e-KTP. 
Jaminan (Assurance) mencakup pengetahuan, kemampuan, kesopanan, dan sifat dapat dipercaya yang dimiliki para staf, bebas dari bahaya, risiko, atau keraguraguan yaitu keinginan para staf untuk membantu warga dan memberikan pelayanan yang bisa memberikan rasa kepercayaan karena warga yang datang memberikan data pribadi berupa Kartu Keluarga sebagai syarat untuk melakukan perekaman e-KTP. Dalam pelayanan e-KTP petugas mampu dan memiliki apa yang menjadi prinsip dan indicator Jaminan (Assurance) yang baik sehingga warga merasa dilayani dalam mengurus perekaman e-KTP di Kecamatan Ciputat Timur.

\section{Empathy (Perhatian)}

Menurut Payne seperti dikutip dalam Djati \& Darmawan (2005) Empati (Empathy) Merupakan pemberian perhatian yang bersifat individu kepada warga dari Pelayanan e-KTP Kecamatan Ciputat Timur. Hal ini dimaksudkan agar pihak Staff atau operator dalam pelaksanaan Pelayanan e-KTP di Kecamatan Ciputat Timur dapat memahami lebih jauh tentang keinginan dan kebutuhan dari Warga sebagai penerima layanan. Empathy yang ditunjukan kepada warga yang hendak melakukan Perekaman e-KTP membuat mereka merasa diperhatikan secara pribadi sehingga warga merasa dipahami apa yang menjadi kebutuhannya.

Empati (Empathy) meliputi kemudahan dalam melakukan hubungan, komunikasi yang baik, perhatian pribadi, dan memahami kebutuhan para pelanggan seperti yang dilihat dari teori Parasuraman, et al (1985) (dalam Tjiptono, 2008) seperti yang dilakukan pegawai menginformasikan apabila ada prosedur Perekaman e-KTP yang baru sesuai kebijakan disdukcapil kepada warga sehingga menghindari kesalahpahaman dalam pelayanan e-KTP, seperti ditengah Pandemi Covid 19 apabila ada staff pelayanan baik di Kecamatan Ciputat Timur atau di Disdukcapil terkena Covid 19 maka pelayanan dikantor tersebut akan dihentikan sementara yang mana akan berdampak pada pelayanan e-KTP itu sendiri.

Berdasarkan hasil wawancara yang dilakukan peneliti terhadap para informan yang berkaitan dengan Empathy dalam pelayanan, Informan 2 (25 Januari 2021) menyatakan bahwa;

"pegawai selalu memberikan informasi apabila ada info dri disdukcapil, contohnya dikondisi covid seperti ini pernah terjadi staf disdukcapil ada yang positif corona, kemudian seminggu kantor ditutup. Maka operator siak yang didisdukcapil sementara tidak bekerja. Maka dampaknya juga kepada pelayanan di ektp kecamatan karena apabila ada restore data warga tidak bisa mengadukan hal tersebut sementara waktu sampai disdukcapil aktif kembali. Kemudian kami informasikan kondisi yang terjadi seperti itu, dan juga apabila ada kendala pada server kemendagri seperti perbaikan atau perawatan kami informasikan kepada warga sehingga sementara waktu tidak bisa melakukan perekaman e-KTP."

Empati dalam pelayanan e-KTP telah ditunjukkan dengan kepedulian pihak pemerintah Kecamatan Ciputat Timur akan kondisi penduduk sebagai penerima layanan, dimana hal tersebut ditunjukkan dengan keterbukaan informasi yang berkaitan dengan pelayanan e-KTP. Selain itu hubungan baik serta komunikasi yang terbuka antara operator pelayanan e-KTP ataupun pemerintah Kecamatan Ciputat Timur telah menjadi hubungan pribadi yang memperhatikan dan peduli akan kondisi dan kebutuhan penduduk dalam mengakses pelayanan e-KTP di Kecamatan Ciputat Timur.

\section{KESIMPULAN}

Dari data temuan lapangan dan analisis dimensi kualitas pelayanan, maka dapat dikatakan pelayanan e-KTP di Kecamatan Ciputat Timur masuk dalam kualitas baik. Dimensi Responsiveness (daya tanggap), Assurance (jaminan), dan Empathy (perhatian) pelayanan eKTP terlaksana dan mendapatkan respon yang baik. Dimensi Responsiveness terlihat dari 
pegawai yang informatif dan komunikatif pada proses pelayanan e-KTP, Dimensi Assurance tergambar dari tanggung jawab pegawai hingga memastikan kenyamanan dan keamanan data penerima e-KTP, dan Dimensi Empathy tampak dari perhatian dan kesopanan kepada penduduk serta penggunaan bahasa yang baik dalam pelayanan e-KTP. Pada Dimensi Tangibility terdapat sarana dan prasarana yang baik, namun masih minim sarana informasi serta fasilitas lahan parkir yang tidak memadai. Selanjutnya Bidang Reliability terdapat penundaan dalam penerimaan e-KTP, sehingga penduduk harus menunggu beberapa hari untuk mendapatkan e-KTP.

\section{DAFTAR PUSTAKA}

Alston, Margaret.,\& Bowles,Wendy. (2003). Research for social workers: an introduction to methods. 2nd ed. Australia: Allen \& Unwin.

Djati, S.P dan Darmawan, D. 2005. Pengaruh Kinerja Karyawan terhadap Kepuasan, Kepercayaan dan Kesetiaan Pelanggan. Fakultas Ekonomi Universitas Kristen Petra.

Fitzsimmons, James A., Fitzsimmons, Mona J. 2006. Service Management: Operation, Strategy, and Information Technology. McGraw Hill.

Kotler dan Keller. 2009. Manajemen Pemasaran. Jilid I. Edisi ke 13. Jakarta: Erlangga

Meleong, Lexy J. 2004. Metode Penelitian Kualitatif, Bandung: Remaja Rosda Karya.

Patton, Michael Quinn. (2002). Qualitative Research and Evaluation Methods, 3rd, USA: Sage Publication

Roderick, James dan Gregory. 2008. Service quality. Diakses melalui http://eprints.mercubuanayogya.ac.id/1011/4/BAB_II.pdf

Sugiyono. 2013. Metode Penelitian Kuantitatif, Kualitatif dan Kombinasi (Mixed Methods), Cet. 4, Bandung : Alfabeta.

Sukoco, Agus dan Nilowardono, S. 2009. Analisa Harapan dan Persepsi Pelanggan atas Servis Quality di PT.PLN (Persero) APJ Surabaya Utara. Jurnal Ekonomi Vol 09 No 2

Tjiptono, Fandy dan G. Chandra. 2005. Service, Quality, \& Satisfaction. Yogyakarta: Penerbit Andi

Tjiptono, Fandy. 2005. Strategi Pemasaran. Edisi Kedua. Yogyakarta: Andi Offset.

Usmara, A, 2008. Strategi Baru Manajemen Pemasaran. Jakarta: Amara Books.

Usman, Husaini dan Akbar, Purnomo Setiady. 2004. Metodelogi Penelitian Sosial, Jakarta: Bumi Aksara.

Undang-Undang Republik Indonesia Nomor 23 Tahun 2006 Tentang Administrasi Kependudukan. 
Undang-Undang Republik Indonesia Nomor 24 Tahun 2013 Tentang Administrasi Kependudukan.

Peraturan Daerah Kota Tangerang Selatan Nomor 9 Tahun 2011 Tentang Penyelenggaraan Administrasi Kependudukan 